\section{V. 結誩}

Cr 量が 25\%で $\mathrm{Ni}$ 量のみが 4, 7, 10\% と異なる 3 種の 2 相ステンレス錩炕ついて，焼なまし温度を主して $900^{\circ} \mathrm{C}$

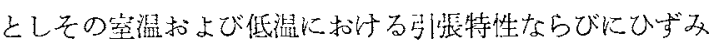

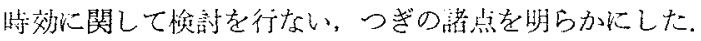

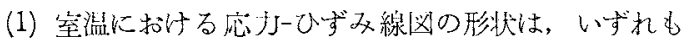
降伏点を示さない通常の材料のそ就と同粎である。乙かし

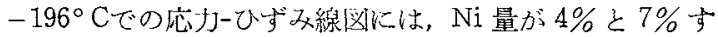
なわち $\gamma$ 相が $40 \%$ と $50 \%$ の場合, 数\%の塑性变形のの方 に降伏点䍐象に類似したるのが現われる。

（2）この降伏点類似の現象は，两試料の場合子も燒なま 乙温度が $1000^{\circ} \mathrm{C}$ でも現われるが, $1100^{\circ} \mathrm{C}$ に高まると消 減する。京た試鸦温度が $-78^{\circ} \mathrm{C}$ に高まっても不明確なも のとなる。

(3) $\mathrm{Ni}$ 量が $4 \%$ と 7\%，特に $4 \%$ の試料の侍一塑性変

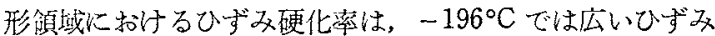

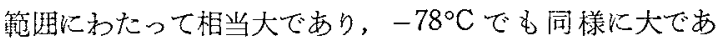
る、しかしこれらのいずれの場合も，一様伸びはそれらの 室温に做方值と同じ程度化大きい，

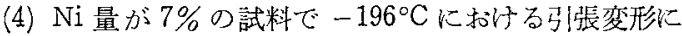
よる前加工の影響を検討した結果，室温飞おける引張強さ は前加工量が增すにつれいちじるしく高まる。

（5）いずれの試料にもひずみ時効が現われ，その程度は $\mathrm{Ni}$ 量が少なく $\alpha$ 相の多いものほどいちじるしい。

(6) 降伏点類似の現象，ひずみ硬化率の増大拉よび前加 工に上る引張強さの向上は，いずれも $\gamma$ 相よりの加工誘起 マルテンサイトの生成に起用するものである。他方ひずみ 洔效では $\alpha$ 相の棵たす役割が大きい。

本研究を行なうに文たり，試料の溶製と分析は大同製銅 株式会社中央研究所に依賴した，記して謝意を表します。

\title{
$\mathrm{Ni}$ を過剩に含む NiTi の時效析出と硬化
}

\section{鈴 木 敏 之增 本 剛 * $^{* *}$}

Toshiyuki Suzuki and Katashi Masumoto : Precipitation and its Hardening Effect in Ni-Rich NiTi. In order to clarify the precipitation and its hardening effect, and the relation between aging temperature and composition of precipitates in $\mathrm{Ni}$-rich $\mathrm{NiTi}$, the changes in hardness and microstructure with aging temperature and time have been examined. The composition of precipitates has also been determined by an electron probe microanalyser.

In the solution treatment of $\mathrm{Ni}$-rich $\mathrm{NiTi}$, the higher the cooling rate the higher becomes the hardness. A significant hardening effect is obtained even by air cooling. The hardness of waterquenched specimens decreases with aging time in the temperature range from 400 to $700^{\circ} \mathrm{C}$. No hardness peak is detected at these temperatures. Optical microstructure experiment shows that no precipitates exist in the water-quenched specimens, but the precipitates appear after aging for 1 to $10 \mathrm{hr}$ at $600^{\circ} \mathrm{C}$ or 0.1 to $1 \mathrm{hr}$ at $700^{\circ} \mathrm{C}$. The compositions of the precipitates determined in the specimens aged at 600 and $700^{\circ} \mathrm{C}$ are close to $\mathrm{Ni}_{3} \mathrm{Ti}_{2}$ and $\mathrm{Ni}_{3} \mathrm{Ti}$, respectively.

The above results indicate that the quench-hardening is caused by quenched-in substitutional defects and that although age-hardening occurs the hardness peak does not appear because the hardening effect is cancelled by lowering of quench-hardening as the number of substitutional defects decreases.

(Received August 19, 1972)

\section{I. 緒言}

$\mathrm{NiTi}$ 相は高温で Ni 過㮃側に伀い非化学量論的維成領

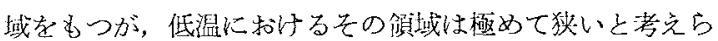
れている(1). したがって，Ni を過剩に含省 NiTiを，析出 を阻止するため高温から急冷した後時效すると析出がおこ り，それ伴って硬化が期待されるが，さきの報告( ${ }^{(2)}$ で明 らかなように，急冷状態の硬さが最も大きく，時效に伴う

** 金属材料技術研究所 (National Research Institute for Metals, Tokyo)

* 1972 年 4 月金属学会東宗大会に発表

(1) たとえば, R.J.Wasilewski, S.R.Butler, J.E.Hanlon and D.Worden : Met.Trans., 2(1971), 229.
硬化は全く認められない，しかし，特效硬化するといら報 告(3) もあり，ま大，Sastri と Marcinkowski ${ }^{(4)}$ 恃急冷状態 ですでに析出が接こり，急冷硬化は $\mathrm{Ni}_{3} \mathrm{Ti}$ の析出または， その前に形成される中間相に上るものであると主張してい る. 著者らは急冷状態の硬化は谏結された構造欠宿による ものであり，電気抵抗の温度変化から求めた $\mathrm{Ni}_{3} \mathrm{Ti}$ の析出 の活性化エネルギーが異常に小さいとも考えられないの

(2) 鉿木政之：金属学会誌，34(1970)，337.

(3) 高构 潔, 池田 唇, 根岸 朗 : 金属学会昭和 41

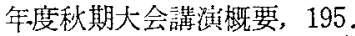

(4) A.S.Sastri and M.J.Marcinkowski : Trans. Met. SOc.AIME, $242(1968), 2393$. 
で，急冷状態で析出がおこるとは考えていない(2)(5)。この ように，析出はいつ始まるのか，それがNiTi の硬さにど の上うに寄与しているのか，といった点については全くわ

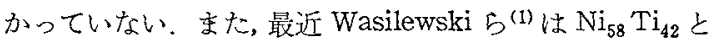
いう組成老もつ化合物相が $625^{\circ} \mathrm{C}$ 以下で安定に存在する ことを見出した，そらならば，時效に竍ら析出物の組成は $625^{\circ} \mathrm{C}$ を境にして異なるはずである。

本研究は $\mathrm{Ni}$ 過剩に含吉 $\mathrm{NiTi}$ の封效化伴ら硬さの举

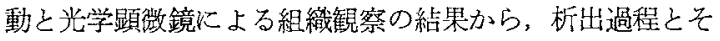
の硬さへの寄与を明らかにしようとするものであり，墔效 温度と析出物の組成との関保も調べた。

\section{II. 試料の作製ならびに実験方法}

試料は原料として電解ニッケル(純度 $99.9 \%)$ とスポン ジチタニウム(純度 $99.8 \%)$ を用い，非消耗電極アーク炉に てアルゴンガス霖囲気中で溶解した．本実験に用いた試料 の化学分析の結果をTable 1 に示す。得られたボタンイ ンゴット怯均一化のため真空中で $1000^{\circ} \mathrm{C}$ 亿 $25 \mathrm{hr}$ 以上加 熱した後，岸素鋼のンースに封入して 900 1000ㄷ Cでプレ 又鍛造し，シースを機解的な方法で取り除いて円板状の試 料とした，試験片はこの円板状の試料から主として放電加 工に上り切り出し， $1000^{\circ} \mathrm{C} て ゙ 1 \mathrm{hr}$ 加熱後水冷の溶体化処 理のあと，所定の熱処理を施し種々の測定に供した，なお 熱処理はすべて $2 \times 10^{-5} \mathrm{~mm} \mathrm{Hg}$ 以上の真空中で行ない，急 冷处理は前報(2) と间じ方法によった。

Table 1 Chemical analyses of Ni-rich NiTi(at\%)

\begin{tabular}{c|c|c}
\hline $\mathrm{Ni}$ & $\mathrm{Ti}$ & Impurities \\
\hline 55.16 & 44.65 & 0.19 \\
\hline
\end{tabular}

実験としては溶体化処理ならびに時効に伴ら硬さの変化 の測定，光学頙改鏡による組織観察，X線マイクロアナラ イザー(日本電子株式会社製 JXA-3A 型) 汇よる析出物の 組成の解析などを行なった。

\section{III. 実 験 結 果}

55.16 at \% Ni を含皇 $\mathrm{NiTi}$ を $1000^{\circ} \mathrm{C}$ K加熱した後, 異 なった冷却速度が得られるように，種々の媒体中に焼入れ たとさの硬さをTable 2 に示す，一般に，析出硬化型合 金の溶体化処理では理想的な過飽和固溶体の状態が最も軟

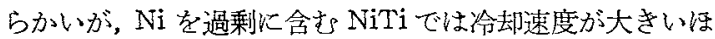
ぞ硬さむ大きく，主た空冷程度の㧍そい冷却速度でも，炉 冷した試料に較べるとかなり硬化する。

$\mathrm{Ni}$ を過剩に含む NiTi は急冷状態が最も硬く，400 $600^{\circ} \mathrm{C} て ゙ 20 \mathrm{hr}$ の時効では析出硬化は全く認められないこ とはさきに報告した (2)，Fig.1 は時效時間を $100 \mathrm{hr}$ とした

（5）鈴木敏之, 增本 骰：金属学会誌，36(1972),796.
Table 2 Effect of cooling rate on the hardness of NiTi containing 55.16 at\% $\mathrm{Ni}$

\begin{tabular}{c|c|c}
\hline Quenching medial & Temperature $\left({ }^{\circ} \mathrm{C}\right)$ & Hardness $D P N$ \\
\hline Iced brine & -6 & 653 \\
Water & 20 & 648 \\
Oil & 20 & 620 \\
Air & 20 & 588 \\
\hline Furnace cooled & & 300 \\
\hline
\end{tabular}

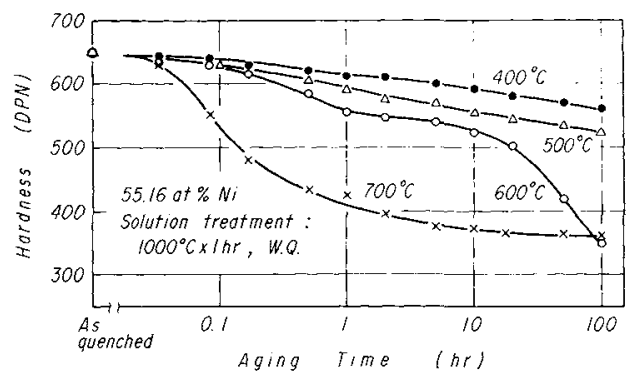

Fig. 1 Hardness vs. aging time curves for $\mathrm{NiTi}$ containing 55.16 at $\% \mathrm{Ni}$

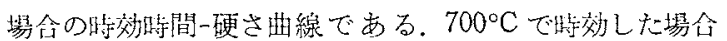

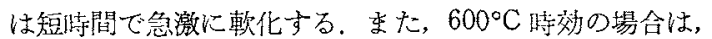
$0.5 \mathrm{hr}$ と $20 \mathrm{hr}$ とに明嘹な 2 段の瑱化が認められるが，硬 化はやはり認められない. $400^{\circ} \mathrm{C} と 500^{\circ} \mathrm{C}$ の時効でも軟化 は極めて技そいが，硬さは単淍に低下している。このよう に，洔効時間を $100 \mathrm{hr}$ とすると， $600^{\circ} \mathrm{C}$ 以上の温度飞お

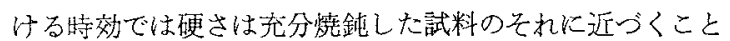
から，析出は漂淩完了すると考えられるが，この間に硬化 が諗められないので, $\mathrm{Ni}_{3} \mathrm{Ti}$ または $\mathrm{Ni}_{3} \mathrm{Ti}_{2}$ の析出は見かけ 上硬さに全く寄与しないと双てよい。

Fig.1 の眭効時閶-硬さ曲線に対応して時效に伴う組織 の変化を示したのが Photo.1〜3である. Photo.1は400 $\sim 700^{\circ} \mathrm{C}$ 亿批壮る $100 \mathrm{hr}$ 時刘後の組織を示したものであ る. $1000^{\circ} \mathrm{C}$ から水冷した 55.16 at \% Ni 含含試料には， 前報(2) でも述べたよらに $\mathrm{Ti}_{4} \mathrm{Ni}_{2} \mathrm{O}$ と又られる相が分散析 出しているが，平衡状態図から考古られる第 2 相の析出は 認められない。これを $400^{\circ} \mathrm{C} て ゙ 100 \mathrm{hr}$ 時効しても，光学 顕微鏡的な变化性全く認められない. $500^{\circ} \mathrm{C} て ゙ 100 \mathrm{hr}$ 時

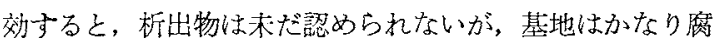
食されや寸くなっており，析出過程が若干進んだことがわ かる. また， $600^{\circ} \mathrm{C} て ゙ 100 \mathrm{hr}$ 時效したものには Widmanstätten 組織が観察され，前述の硬さの挙動からも析出は ほぼ完了したものと思秃る。同温度に括ける $1 \mathrm{hr}$ およ び $10 \mathrm{hr}$ 時效後の組織を Photo.2に示したが, $1 \mathrm{hr}$ 時㬵し たものは部分的に腐食されやすくなっているが析出物は認 められず, $10 \mathrm{hr}$ 時効したものには Widmanstätten 組織が 認められる。時效温度を $700^{\circ} \mathrm{C}$ とした場合の組織の変化 をPhoto.3 亿示すが，硬さの挙動から子測されたように， $1 \mathrm{hr}$ の㭙効ですで多くの析出物が認められる。しかし， 析出物の形態は $600^{\circ} \mathrm{C} て ゙ ~ 100 \mathrm{hr}$ 時效した場合と明らかに 


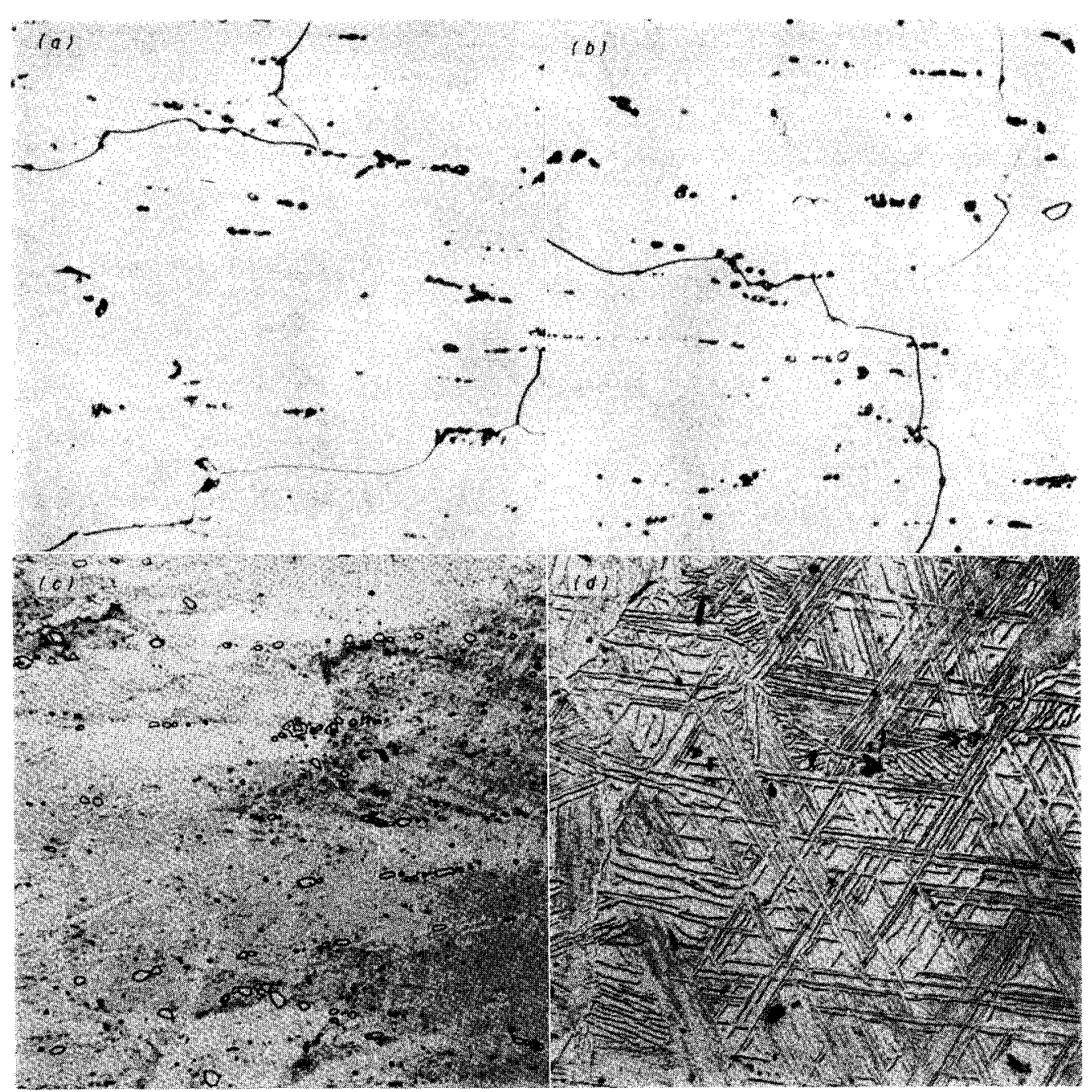

Photo.1 Microstructures of NiTi containing 55.16 at $\% \mathrm{Ni}$ : (a) as quenched, (b) aged at $400^{\circ} \mathrm{C}$ for $100 \mathrm{hr}$, (c) aged at $500^{\circ} \mathrm{C}$ for $100 \mathrm{hr}$, (d) aged at $600^{\circ} \mathrm{C}$ for $100 \mathrm{hr}(\times 250)$

異なっている。

光学顕微鏡観察で時效温度によって析出物の形態が異な ることがかかったが，それらの組成をX線マイクロアナラ イザーによって解析したところ，600C で時效した場合は Wasilewski ら ${ }^{(1)} か^{2} 625 \pm 25^{\circ} \mathrm{C}$ 以下で安定に存在すると主 張している $\mathrm{Ni}_{3} \mathrm{Ti}_{2}$ K，また $700^{\circ} \mathrm{C}$ て時效した場合は $\mathrm{Ni}_{3} \mathrm{Ti}$ に近い組成をもつ析出物が存在することが確かめられた。

\section{IV. 考察}

$\mathrm{Ni}$ を過剩に含む NiTi の時效に伴ら硬さの挙動から析 出と硬さとの関係を考兵ると，次の 3 つ分けることがで きる。すなわち

(1) Sastri とMarcinkowski(4) が主張しているょうに, 急冷状態すで析出がおこっているか，あるいは，中間段 階まで析出過保が進行して和り, その結果急冷状態で硬化 がおこる，旮して，時效に伴う軟化は過時效に上るるので ある。
（2）急冷状態の硬化はすでに報告したように構造欠陷に

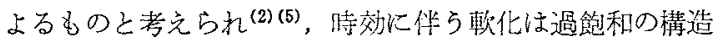
久陷の消滅によるもので，元の結果 $\mathrm{Ni}_{3} \mathrm{Ti}$ なたは $\mathrm{Ni}_{3} \mathrm{Ti}_{2}$ の 析出が拈こるが，これらの析出はNiTi の硬さに全く寄与 しない。

（3）急冷状態の硬化は（2）と全く同㥞であるが，時效比

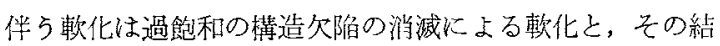

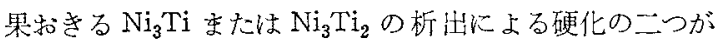
合成されたもので，見かけ上析出硬化は観察されない。

本章ではこれらの中どれがおこっているかを明らかにす るため考察を進める。

\section{1. 急冷硬化と析出}

まず，急冷状態の硬化は析出化よるものであると仮定し て実験結果を再検討してみる。 55.16 at \% Ni を含む $\mathrm{NiTi}$ に種々の冷却速度で溶体化好理を施したところ, Table 2 から明らかなよらに，冷却速度が大きい汪ど便さも大きく

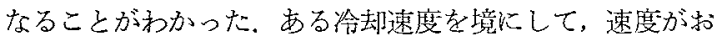




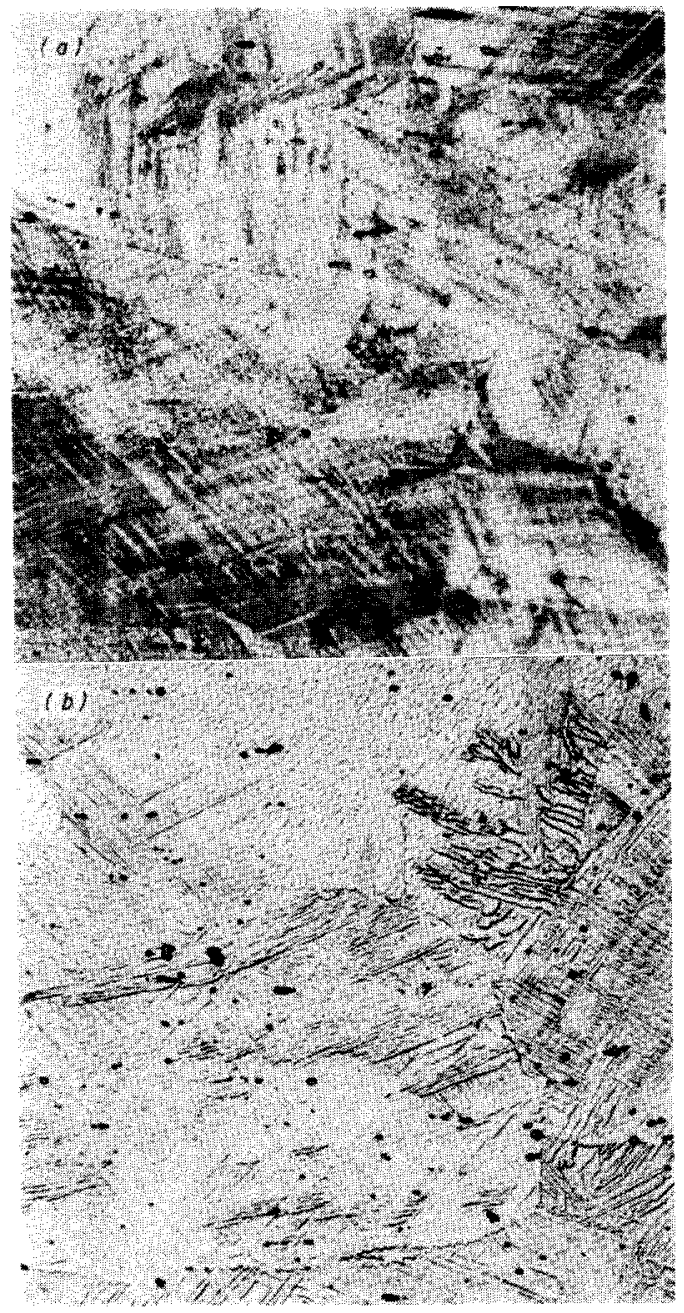

Photo.2 Microstructures of NiTi containing 55.16 at $\% \mathrm{Ni}$ aged at $600^{\circ} \mathrm{C}:$ (a) for $1 \mathrm{hr}$, (b) for $10 \mathrm{hr}(\times 250)$

そいため溶体化処理が元全に行なわれず，析胡がおるるの

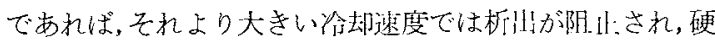
さは少なくとも大きくはならないはずである。 むし水冷に よっても析出を阻作することができないとすれば， $\mathrm{Ni}_{3} \mathrm{Ti}$ または $\mathrm{Ni}_{3} \mathrm{Ti}_{2}$ の析出の活性化去ルギーが翼常に小さく なければならず,さらに, 管冷程度の泠却速度でもかなり 硬化可るとい5笑結果を説明することがすずかしくな

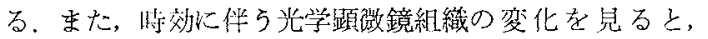

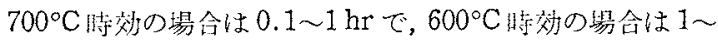
10 hrで析H物が浔められるよ5になるが，急冷状態では

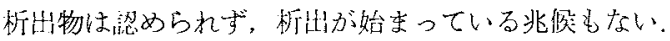

このように，急冷状態で析地が扎こるとしたのでは，笑

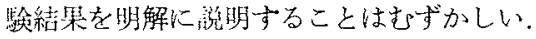

それでは，急冷硬化が構造欠陷によるとした場合はに゙う であ万らか。さきに述べたよらに，NiTi相の組成領域は

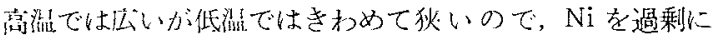

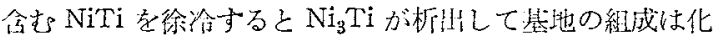

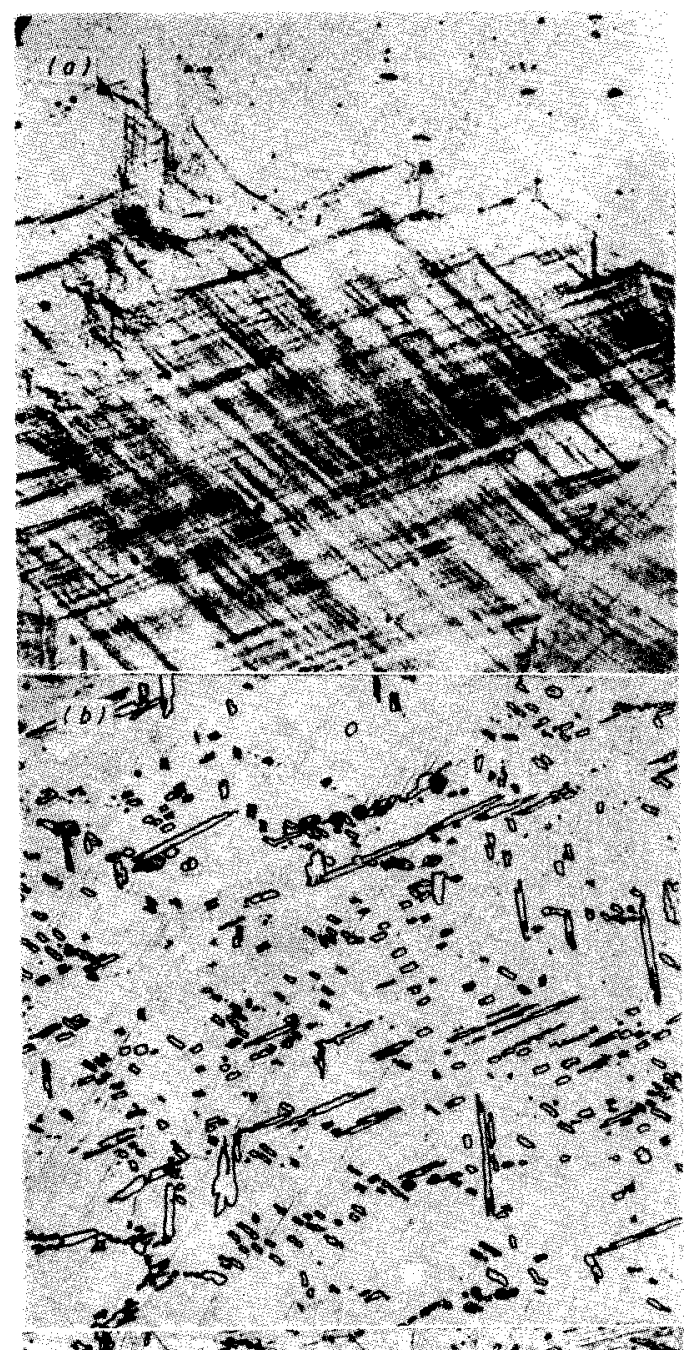

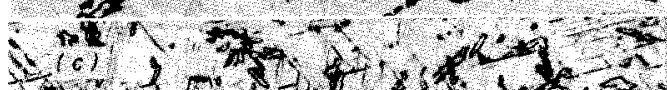

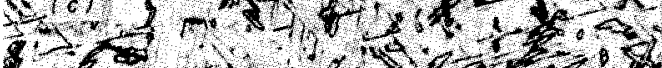

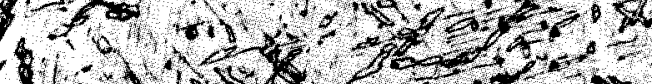

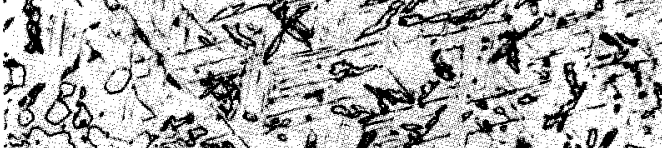

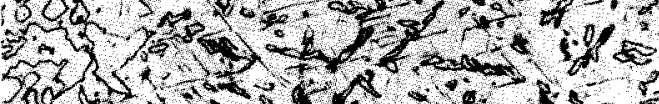

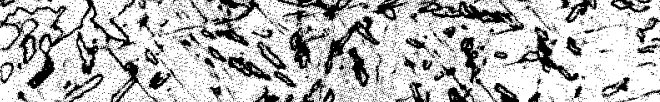

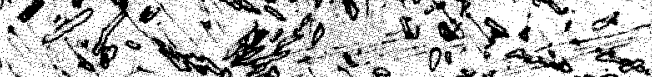

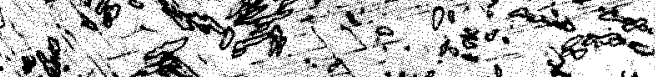

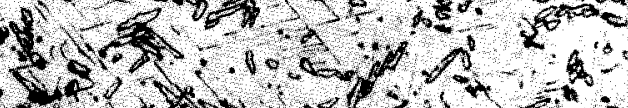

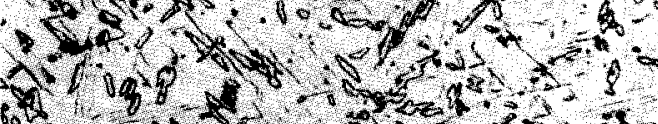

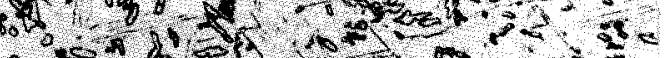

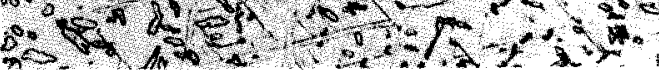
Photo.3 Microstructures of NiTi containing 55.16 at $\% \mathrm{Ni}$ aged at $700^{\circ} \mathrm{C}$ : (a) for $5 \mathrm{~min}$, (b) for $1 \mathrm{hr}$, (c) for $10 \mathrm{hr}(\times 250)$

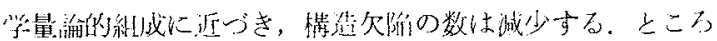

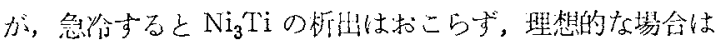


化学量淪的組成からのずれに相当するだけ情造欠宿を含九 だ状態が室温委でもち来たされる。いま，北化学量諭的金

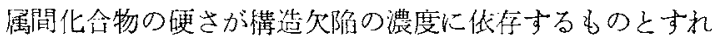
ば，溶体化処理の冷却速度が大で西るほぼ急冷状態の硬さ が增すことは至極当然のことであうう。立た，空冷程度の

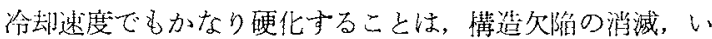
いかえ机ば $\mathrm{Ni}_{3} \mathrm{Ti}$ の析出，の活性化エネルギーが大きく， 相当数の搆造欠孱が残留するために依然として硬化が办ら れると考穴机ばよい，事実， $\mathrm{Ni}_{3} \mathrm{Ti}$ の析出の活性化亲ル ギーは前報(5)で報告したよらに $3.7 \mathrm{eV}$ とかなり大きい。 老机に，急冷状態では析出は全くおこらないのであるか ら, 光学䫓微鏡組織にも何等問題はない。

このよ5に，急冷硬化は凍結された過飽和の構造欠宿に よりひきおこされると考えれば実験結果と矛厝しない。

したがって，柋冷した非化学量論的 NiTi 相は，理想的 な溶体化処理が行なわれたとすれば，NiTi 規則格子の基

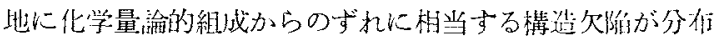

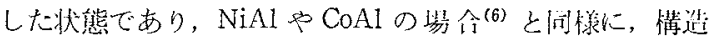
陌が硬化をもたらしているとみられる。

\section{2. 時効析出とその硬さへの寄与}

前節の考察で，Ni 老過剩に含むNiTi の急冷状態の硬化

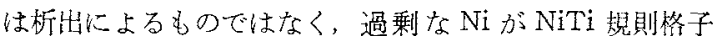
中に構造欠陥として存在することによるものであることが はっきりした，したがって，析出は时効の途中でおこると

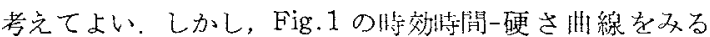
と、いずれの温度においても硬さのピークは癹められな い.このことから直ちに，析出はNiTi の硬さにほとんど

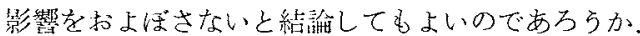

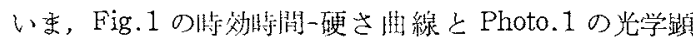

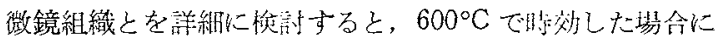
二つの特異な垷象が垫められる。その一つは硬さが胿間と 共に举淍に減少せず，2段の軟化を示すこと，他の一つは $1 \mathrm{hr}$ 時效した試料と $10 \mathrm{hr}$ 時効した試料で，継織が全く異 なるにもかかからず硬さが伍とんど韋わないことである。 こ礼らはいずれる，化合物の形成に上り構造欠陷が影純に

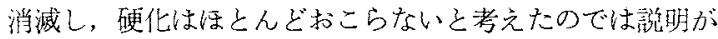
つかない.

それでは，構造欠陷の消隇による軟化と析出硬化とが同 睦に抗こっていると考えたらどらであろらか。

$\mathrm{Ni}$ 過剩な NiTi の構造知陷は Ni 原子が Ti の格子点に 入った substitutional defect と考えられる(7)。その $\mathrm{Ni}$ 原 子が $\mathrm{Ti}$ 原子と結合して $\mathrm{Ni}_{3} \mathrm{Ti}$ な注 $\mathrm{Ni}_{3} \mathrm{Ti}_{2}$ を作り析山 するのであるが，化合物を作っても基地の Ti 原子の濃 度は活とんど変化しないと俶起すると, substitutional defect の数は(1)式にしたがって指数関数的に減少すると みてょいであうう。

(6) J.H.Westbrook: J.Electrochem.Soc., $103(1956), 54$.

(7) T.Suzuki and K.Masumoto: Met.Trans., 3 (1972), 2009

†この場合は $K=1$ として求めた。

$$
n=n_{0} \exp (-K t)
$$

ここで $n$ は substitutional defect の濃度, $n_{0}$ は $t=0$ のと きの substitutional defect $の$ 濃度，Kは级応恒数， $t$ は时

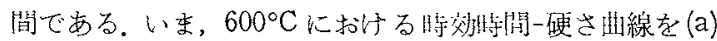
とし, substitutional defect の数の跱间による変化を示す

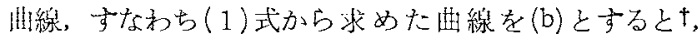

Fig.2のよらに表わされる。構造欠陷比上る硬化がその数 に比例するとすれば，硬さも(1)式にしたがって変化する はずである、全軟化腈線(a)から substitutional defectに 上る硬化(b) を美し引くと沮線（c）が得られるが，これが構 造欠陷以外の原因による硬化分であり，析版にるものと 洘えられる。このように考えれば，特に 2 次硬化などを考 えなくても，赖化が2段に乱こることる明解に説明するこ とができるし，䏣線(c)のピークは1〜10 hr の間にあるこ とから，曲線(a)だ计では詵明不叮能な組織と硬さとの関 係子理解できる。

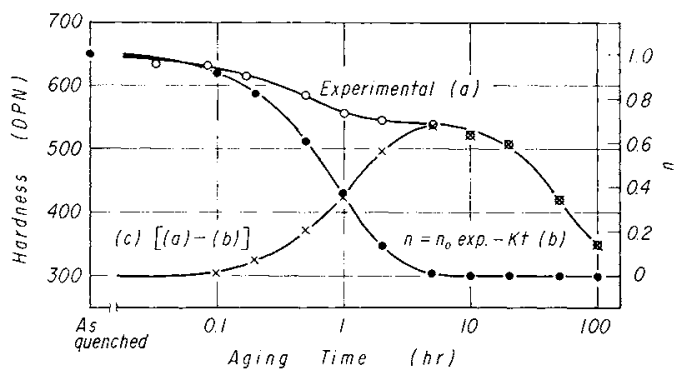

Fig. 2 Schematic illustration of the contribution of precipitation hardening to the hardness of Ni-rich NiTi

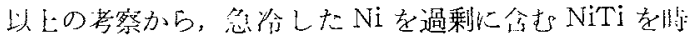

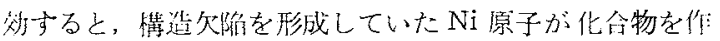
り析汁するため, 棈造欠鲉による硬化は減少するかわりに

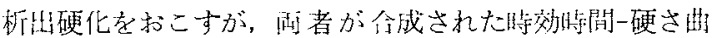
線が得られるため，見がけ，硬さのピークは示さないも のと考えられる。

\section{V. 結論}

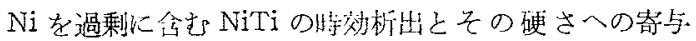
ならびに時效温度と析出物の組成との関係を明らかにする

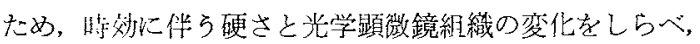
さらにX線マイクロアナライザーによる析出物の解析を行 ない, 次の結錸を得た。

(1) 析出は急冷状態では扎こらず，将效の途中で抏こ る.したがって，哭冷硬化は析胡によるのではない。

(2) 急冷硬化は凍絈された構造欠陌 (substitutional defect)によるものである。

(3) 封効析出はNiTiに硬化をもたらすが，それに伴う substitutional defectの消隇のため急冷硬化は減少し，闻

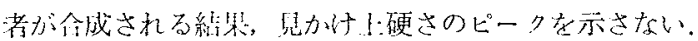

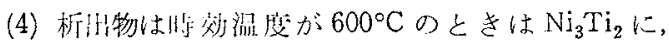
$700^{\circ} \mathrm{C}$ のときは $\mathrm{Ni}_{3} \mathrm{Ti}$ に近い組成をもつものである。 